\title{
Collaboration of digital payment usage decision in COVID-19 pandemic situation: Evidence from Indonesia
}

\author{
John Tampil Purba ${ }^{a^{*}, \text { Sylvia Samuel }}{ }^{\mathrm{a}}$ and Sidik Budiono ${ }^{\mathrm{a}}$
}

Article history:

Received: May 10, 2021

Received in revised format: June 30,2021

Accepted: August 26, 2021

Available online: August 26, 2021

Keywords:

Digital Payment

Financial technology

Service industries

Online payment

Online Transportation

Trustworthy

COVID-19

\begin{abstract}
This study aims to provide an attempt by raising a framework for assessing the digital technology perspective in the application of Financial Technology by consumers, especially in the era of the Covid19 pandemic in 2020 in Indonesia. Digital technology in Fintech in collaboration with online transportation is utilized by quite a few big firms in Indonesia to meet the needs of consumers during strict, large-scale restrictions but not lockdown. This paper mainly acknowledged the problem related to digitizing solid digital technology which prioritizes technology 4.0. Digital technology applications, especially among the millennial generation regarding the accessibility, pace and value of financial services are increasingly in demand. This research spent 5.5 months with millennial respondents who are accustomed to using everyday technology applications in Jakarta, Depok and Tangerang and surrounding areas. The method of analyzing data in a quantitative way to find findings is complemented by discussion. The findings prove that; All variables have positive strong effect on driving the choice of digital FinTech technology in ordering food and others to survive during the pandemic of COVID-19. The existence of digital-based technology applications related to the internet, big data, smart mobile phones, safe and comfortable technology power has motivated consumers to use them. In conclusion, there are several new business opportunities open to newcomers in the digital financial sector and other accessories using information systems and information ecosystems.
\end{abstract}

\section{Introduction}

Technology allows innovation in many sectors especially financial technology services (FinTech) is expanding speedily. With the advance of technology, many factors need to be considered, because technology might lead into the opportunities, risk in financial stability, policy, and regulation. This is especially essential as some innovations might not have been tested through financial payment, therefore major selections at an early stage are really vital. The elected officer must continue to update the regulation of Financial Technology and mitigate the risk, since the use of FinTech increased in daily life. Specifically, the G20 conference has recommended the Financial Stability Board (FSB) strengthen the scanning date and addressed regulation about FinTech from a financial perspective (Financial Stability Board, 2020). Currently, online-based transportation modes are becoming popular in Indonesian society, especially in big cities, their existence is increasingly vibrant, decorating the diversity of conventional transportation modes that have existed previously. The presence of GOJEK, Grab bike, Grab taxi, Uber, and like, both bike and car online applications, was accepted by the public, because besides being easy to order, it was

* Corresponding author.

E-mail address: john.purba@uph.edu (J. T. Purba)

(C) 2021 by the authors; licensee Growing Science, Canada. doi: $10.5267 /$ j.ijdns.2021.8.012 
practically in their hands. In addition, in terms of security, the identity of the driver can be easily accounted for, which is more attractive, the cost is cheaper than renting other conventional modes of transportation.

Interestingly, the public's interest in becoming an online-based transportation driver is increasing every day; reportedly the income is quite tempting. Drivers of online-based application transportation modes are not in demand for unemployed people, housewives, students and even those who are already working at night are also taking on this online-based transportation driver to increase the cost of daily necessities which are increasingly felt to skyrocket. Online-based transportation mode services in addition to providing a mode of transportation can also be used for the purposes of ordering daily food which is covered in advance by the management of an online-based transportation mode application, after the goods are delivered to their destination, then the customer will replace several shopping costs incurred plus the cost shipping service fees. The advantages from online transportation application are very real, for example, if there is a family who is having a hard time being unable to cook for their family's consumption with the sophistication of this online-based transportation mode, from the bedroom alone, you can order food menus that are ready to be served to their families. The increasing request for community mobility, naturally, needs online transportation firms to facilitate customer movement from one point to other points speedily. Recently, there are the latest breakthroughs, namely online application-based transportation innovations, that are reinforced by the advance of telecommunication tools connected through mobile phones. This application is based on an amalgamation of transportation services for motorcycle taxis and communication technology. Weber specifically based on the rationality of social action classifies few social movements in their sociology. Type of Social of action includes firstly Instrumental Rational, Value Rational, Affective, and lastly Traditional Action (Pedler, 2020). Through these various types of social actions, the extent of study will discuss the social actions taken by users of the Go-Jek application transportation based, who priorly experienced the convenience of online transportation. The existence of online mode transportation makes people have various transportation choices, so they must decide which transportation provides the best price. Of the many online application-based transportation available in Indonesia, Go-Jek is one of the most utilized by the public. This analysis on the global research institute Growth for Knowledge (GFK), showed that Go-Jek online application customers reached 21.6\%. Go-Jek is a social technology company that aims to improve the welfare of workers in various informal sectors in Indonesia. In addition to communication services and technology, online application-based transportation is also provided with a Global Positioning System feature or better known as GPS to provide information on the whereabouts of drivers, and users with the closest route. Additionally, in daily life human beings are very mobile, it requires supporting transportation facilities. The nature of urban society, in general, is dynamic, keep moving, and adapting to circumstances. Likewise, with changes in the choice of transportation made for the activities (Damaini et al., 2018). The use of Go-Jek by the people at Surabaya can be presumed due to the disappointment that arises from the weakness of the existing mass transportation facilities. Please note, there are problems that cannot be separated from mass transportation, including lack of fixed timetable, a road map that drives passengers to change line or transit, massive number of passengers during peak hours, bad environment conditions, and how to drive the vehicle with safety conditions. In addition, during pandemic COVID-19, while the government implemented staying at home, working from home, the usage of online transportation increased significantly both for e-commerce and ordered food. Rifusua states that good public transportation must meet three basic criteria, namely: comfort, security, and speed (Amajida, 2016; Rifusua, 2010). First, the first criterion is comfort. The comfort aspect can be felt by passengers if there are facilities such as air conditioning, and it is closed from motor vehicle pollution fumes. Next, the criterion is safety. The security system on boarding and disembarking passengers must be at a designated bus terminal or stop. Thirdly is speed. Fulfillment of time rapidly and precisely to arrive at a destination, such as a train that has a special line so that the estimated time can be appropriate. But, mass transportation, which is also the transportation of public services in big cities in Indonesia, rarely meets these three criteria.

\section{Literature review and hypothesis development}

\subsection{Financial technology}

Financial technology (FinTech) is a system that is designed to assess and produce finance. Globally, FinTech has gained notice as one of the demanding technologies that can allow companies to engage productively and efficiently in disruption 4.0 (Wonglimpiyarat, 2017). Broadly, analyze technological transformation, especially in Financial technology that is quite challenging, as can be seen from a traditional point of view that only centers on products, prices and supply / demand (Iman, 2020). The term of FinTech comes from "financial" and "technology" can be express in widespread relation of latest and used of things involved of technologies that set up an activity of financial service (Gomber et al., 2017), or cross function department consists of finance, management of technology, and management of innovation (K. Leong, 2018). With this background, the disclosure of financial technology has led to "financial service disintermediation" together with the new regulation to protect customers and venture capitalists (Giudici, 2018; Guo \& Liang, 2016). Instantly, Financial Technology newbies can mitigate the intermediary cost and minimize the capital requirements that normally are associated with conventional banking facilities (Iman, 2020). The use of huge amounts of data analytics and information of science has affected how data is detained, exercised and analyzed, which in return mitigate the cost heavily (Giudici, 2018; Iman, 2020). FinTech is one of the technologies that would revolutionaries many industries, especially the transportation industry. In addition, FinTech has expanded speedily in distinct circumstances, most likely contributing to new ideas of product and service in applying ultramodern technology (Alt et al., 2018; Gomber et al., 2017; Iman, 2020). Nevertheless, the supervision and scope of delivery of the goods 
and services by FinTech companies increased broadly. Scholars added additional new descriptions and perspectives about financial technology (Gomber et al., 2017; Wonglimpiyarat, 2018), while other studies focus on interaction and the ecosystems (Iman, 2020; Kang, 2018; I. Lee \& Shin, 2018; C. Leong et al., 2017; Thompson, 2017). Furthermore, some studies carefully review FinTech specifically on the adoption and spreading of financial technology goods and services on customer boundaries, however very few studies specialized on the production side. There is a review about digital e-commerce finance surrounding almost every product, services, technologies, and infrastructures that allow each individual and firms to obtain the function of online payment, and any other facilities that can be finished by arm length without visiting directly in person to the service provider (Ozili, 2018). Alternatively, after extensive review, one of the authors define the designation of FinTech as established on weak foundation and encounter from semantic issues (Schueffel, 2017). Borrowing from (Dorfleitner et al., 2017) stated that the FinTech industry can be divided into four categories such as financing, asset management, payments and other FinTech. FinTech that belongs to payment only on mobile payment Fintech. "Mobile Payment" is explained as several functionality offered by smart phone technologies to finalize the payments, online virtual bank, e-Wallets, and peer to peer transfer in exact time. Continuously, FinTech startup revolution in India and the rest elsewhere in Asia. Likewise, mobile payment has been expected as one of the new business models in sequence to implement payment solutions for customers (Xue et al., 2021). Therefore, FinTech lies beneath innovations, deepening appreciation and technological development (Dranev et al., 2019).

\subsection{Trust}

Trust is the idea of belief, self-confidence, hope, integrity, dependence, reliability, the ability for an entity character of a thing (Agag \& El-Masry, 2017; Kim, 2000). Trust is defined as an individual who is ready to take a risk and to become exposed to the behavior where the others will fulfill the expectations (Ben Sedrine et al., 2020; Pavlou \& Fygenson, 2006; Zheng et al., 2019). Nowadays, in disruptive innovation, especially electronic payments using Fintech, the role of trust is extremely vital because of the massive data and multidimensional data involved in this area (Hu et al., 2019). In addition, massive and multidimensional data, particularly important to learn trust processes, influence the security of future customers and willingness to take on, along with which elements influence trust (Koksal, 2016; Malaquias \& Hwang, 2016).

According to Kesharwani and Bisht (2012), trust can be described as customers' altogether effectiveness of things and developed that trust able to convince practices, and trust is created by individual deep-rooted attributes (Hu et al., 2019). Because of deep-rooted aspects of financial technology, the acceptance of Fintech has, beyond doubt, a chance of insecurity and some research has explored that trust is almost like image of brand and risk that consumers feel (Koksal, 2016). Moreover, based on customer perceptions, brand images of banks or any other online platforms and perception of service risk have enormous impact on trust of services and security. Instantly, trusts of services plays a vital role in analyzing electronic financial transactions, where customers are vulnerable to greater risks of uncertainty and a sense of loss control (Lu et al., 2011; Slade et al., 2015; Zhou, 2013). According to Mcknight et al. (2002, 2011) and Xin et al. (2015) trust typology and conceptualized trust are trusting beliefs, trusting intentions and trusting behaviors. The outcome of trust, as a unitary construct, on behavioral intention has obtained notable support in mobile payment context (Chandra et al., 2010; Lu et al., 2011; Slade et al., 2015). The main problem for a customer is difficult to trust online mobile payment platform service and try to avoid uncertainty. The next steps to increase customers' confidence to use cashless payment are the company must build psychological bonding with customers by communicating all the information and product knowledge through advertisement, newsletter, and social digital marketing tools. In addition, the approach t eliminate uncertainty, the company must build a stable function of mobile technology and regulations, laws and guarantees that make a customer feel safe to do transactions with the company (Mcknight et al., 2011).

\section{$\mathbf{H}_{1}$ : Trust positively impacts Benefit Variable.}

\subsection{Self efficacy}

Theory of self-efficacy originally from Social Cognitive Theory developed by Albert Bandura (Shea \& Bidjerano, 2010; Yokoyama, 2019). Shiau et al. (2020) stated human behavior and motivation are induced by an independent's belief in oneself about one's own abilities. According to Bandura (1982) self-efficacy can be described as an individual's perception of their personal capacities to make a decision that is essential to accomplish their fulfillment. Departing from (Bandura, 1999) mention, the theory of social cognition is an exact assessment of individual value that has substantial foundation and control the effort of consumers while using it and the length of how customers can defeat the difficulty. Moreover, prior study stated, self-efficacy has been distinguished as an important factor that has direct or indirect relationship affects user intention to use FinTech service context (Choi, 2018; Kim et al., 2016; Shiau et al., 2020). Alternatively, few scholars mentioned that selfefficacy has immediate effect, but can't use it to determine a concept on a universal level since functions to use in FinTech mobile payment services are domain specific. Hence, Cassar and Friedman (2011) developed the usage of self-efficacy instead of widely used self-efficacy because efficacy has appeared to come across with potential powerful prediction when illustrating certain circumstances (Fryer et al., 2020). Types of self-efficacy include technological, computer, internet, smartphones, investing, financial (Shiau et al., 2020). Furthermore, online internet users must show sufficient self-efficacy as a guide of online 
shopping at marketplace and when paying online transportation (San-Martín et al., 2020). Moreover, when a customer demonstrates their level of technological self-efficacy and considers their capacity to accomplish an activity in a mobile phone. Thus, self-efficacy for financial technology mobile payment services includes two self-efficacies containing technological and smartphone self-efficacy.

\section{$\mathbf{H}_{2}$ : Self Efficacy to Benefit is positive significant toward Benefit Variable.}

\subsection{Security}

Internet settlements are always subject to numerous information security threats, consumers' confidence is fundamental in website purchases and is affected by perceived information security safety systems (Tsiakis, 2012). Due to deception activity through online transactions is one of the roots of financial loss between consumers, however, it also attacks users' personal information, which becomes a concern for numbers of online users (Lee, 2009). In addition, according to (International, 2019) stated that financial services firms compete with many start up digital companies such as virtual organization, digital peer to peer lending. The rapidly changing environment and the advancement of technology, traditional banks must adapt and manage more agile tactics for their own technology infrastructure. The security threats are changing for fintech, traditional and other online electronic transfer payment organizations". Since the pace of digital disruption speeds up and innovative advanced technologies reach the market, all sectors are having to adapt. Broadly, FinTech has defined four types of elements of risk that have essential roles include financial, legal, security and operational risks (Ryu, 2018). Security is classified as one of the elements of risk that will be focused in this research. Risk of security stated as greater possibility forfeiture because of deception activity that attacks the safety from virtual online purchase in financial technology. Moreover, major transformation changes of a bank platform used to take place between two to five years. However, since banks need to adapt to the fast pace of change against other players, they upgrade the systems without legacy regulation. Instantly, this approach has significantly increased speed to customers and boosted complexity to security risk management, which is still in innovators or research and development stage. According to (Fang et al., 2014), noticed, with respect to business to consumer relationship, safety was an important factor for consumers to accept any risk associated with a transaction during online payment. In the meantime, (Kim et al., 2010) studied some issues about e-payment security from the point of view of customers and discovered that perceptions of the security of e-payment systems have become a core issue in the growth of e-commerce in the marketplace. Due to various methods of payment systems ready for online customers. These include credit card, debit card and virtual card, as well as new forms of technology payments such as e-wallets, e-cash, mobile payment and cash on delivery (COD) (Strzelecki \& Rizun, 2020; Teoh et al., 2013).

Based on some scholarly views, online stores and e-commerce platforms are equipped with SSL (secure socket layer certificate) and HTTPS encryption. Regarding this certificate issues can be described from A to F grade. Instantly, the better grade analysis received by the online store, than less security issues involved by the store. Additionally, SSL security certificates assure customers that their data will not be disclosed to third parties (Strzelecki \& Rizun, 2020), as well as perceived security as probability which customers believe that their payment information transaction will not view by others, falsified by unauthorized users during the finalized transaction. Therefore, security means users have their own safety expectations that must be fulfilled by all parties in this transaction process (Waheed et al., 2013)

\section{H3: Security positively influences Benefit Variable.}

\subsection{Ease of use}

Innovative FinTech evolved into a mobile payment service for online transportation transactions. Kim et al. (2015) defined that ease of use is when consumers' confidence that the use of FinTech service is easy and does not need too much effort to learn. The technology acceptance model (TAM) (Davis, 1989; Wu et al., 2016) is most frequently used to predict used behavior, intention to adopt or to accept mobile payment. Ease of use developed by combining internal control (advanced technology, such as computer and smartphone) and external control (facilitating condition) into TAM (Kesharwani \& Bisht, 2012; Venkatesh et al., 2000). In addition, Ease of use can be explored by the number of efforts that a user dedicates their time to use a FinTech mobile payment service to make online transportation payment. Time consumed by using mobile payment service is a constraint factor on customers. In addition, ease of use points out to when a customer feels it is easier to use a certain technology more than other after time is controlled (Kim et al., 2015). In a meantime, ease of use can be determined to the stage at which an individual believes that using a certain system would be effortless, to simplify, perception on how easy to use an application system (Junjie, 2017). Furthermore, Fintech services come up with better services and customer experiences for many types of customers such as bank, transportation, e-commerce, and marketplaces, which can cover for the traditional banking weakness and other services to meet the personalized needs of customers (Hu et al., 2019). Ease of the use of Fintech is the key component that shapes the choice by users (Abbad, 2013). As Riquelme and Rios (2010) reviewed, usefulness has importantly influenced user point of view and readiness to embrace mobile payment applications when consumers operate smartphones for finalized a payment. Moreover, if Fintech service is friendly to the user, easy to use and operate, then customers are ready to use them. 
Therefore, ease of use pointed out the degree where customers feel ease to give a try in the process of learning to use online mobile payment services. Continuously consumers are obviously to accept the internet banking services where there is ease of use in operation to in terms of transportation online payment service, some study claimed that technology readiness and specialized knowledge will affect ease of use (Ji-Eun \& Minsoo, 2011).

\section{$\mathbf{H}_{4}$ : Ease of use positively influences Benefit Variable.}

\subsection{Benefits}

Financial Technology brings benefits for customers especially for both products and services. According to (Narwal \& Nayak, 2019) continuation of virtual online payment transaction in financial technology depends on financial technology consumers widely component evaluation of the use of online payment by applying Theory of Reasoned Action (TRA) through online payment context. Mobile payment widely well known as customers choose accessible and valuable service, and a customer made a final decision to use the services to receive a benefit from the features (Kim et al., 2008). Explanation of benefit is a customer point of view about the function of online payment that will provide a good result. Benefit can significantly affect mobile payment usage (Akintan et al., 2019; Li et al., 2012). Based on much information, according to World Bank (Fintech: The Experience so Far - Executive Summary, n.d.) stated benefit of FinTech lead to substantial financial includes, enlargement of financial sector to non-financial services, and the broadening of personal services to individual, since almost more than eighty percent people in the developing country has used smartphone. Furthermore, the benefit of FinTech has a greater important effect to serve affordable, convenient, free of risk payment, and assist customers transfer from conventional transactions to online FinTech digital platforms or cashless payment (Murthy et al., 2019; Ozili, 2018). FinTech has benefits to financial and monetary system regulators that can minimize the payment of using fake money. Moreover, customers have wider control of their personal financial, speedily financial decision maker and capability to send and receive money instantly (Ozili, 2018). Furthermore, Fintech can bring economic benefits such as lower transaction and capital cost for customers. Convenience can be described as one of the benefits from Fintech. Instantly, it relates to flexibility in time and can be accessed anywhere through a smartphone if it has internet connection (Lee \& Teo, 2015). Next, Financial technology items will be better adjusted to the needs of small-scale business. This includes e-commerce marketplace, merchant, e-commerce finance, supply chain and financial trading. Hence, financial innovation solutions can be important to help small-scale businesses by supplying them superior cash flow, build up working capital management, and secure funding. Thus, the benefit of FinTech will continue to evolve and need to be supported by prosperity of each individual and business that have funds in customer accounts to finish several online transactions, especially online transportation, normally, customers will receive special treatment, if they do transactions using FinTech mobile payment. Special treatment here means customers might receive benefits like cash back in points value which can be used for the next transaction.

\section{H5: Benefit positively influences Financial Technology Variable.}

Fig. 1 draws the Research Model Framework, in which online transportations are affected by trust, self-efficacy, security, ease of use, in the model, benefits in this framework as the mediation for financial technology.

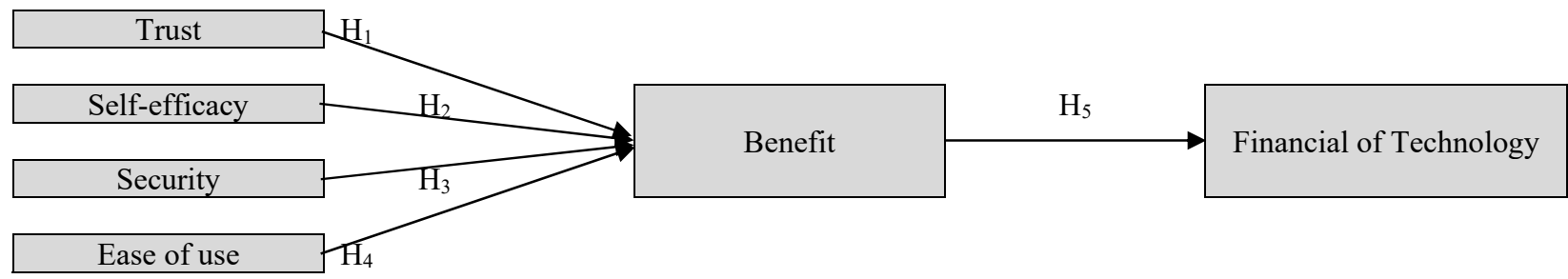

Fig. 1. The proposed study

\section{Methodology}

\subsection{Data}

The research model used in this study is to test the utility of the use of financial technology by urban customers during the COVID-19 pandemic in Indonesia. In determining the topic of the study, the authors chose those who often use digital technology, namely digital payments in transactions. The election is for those who use digital technology which is of interest in Jakarta, Depok, Bogor, Bekasi and surrounding areas. Seen from the perspective of the respondent's research methods, it seems that they have fulfilled a logical frame of mind. This research design used a quantitative approach through a survey questionnaire. The population in our research come from those people who know and are familiar with the application of Digital Technology with Financial Technology organized by digital technology companies such as Go Pay and Ovo, and the like in Indonesia. The author uses the respondent selection method so as not to be mistaken in answering questions that have 
been designed previously. This was done because of the population filtering as suggested by (Sun \& Saenko, 2016) the determination of the sample is very important in terms of ensuring that the data collected by the researcher and the resulting data are reliable and representative of the population. In line with this, (Sugiyono, 2018) also states that population is an important element in research and is the overall observation that will be studied.

\subsection{Analysis procedures}

The study used a quantitative approach where the research data was collected using a survey with a sampling method, namely nonparametric with a purposive sampling approach. Given that research on digital technology is still limited, only those who are used to using the application in question. One of the scholars stated that respondents can only provide the data needed for further analysis of a group with certain characteristics (Ghozali, 2014). The characteristics as respondents are those in the $Y$ and $\mathrm{Z}$ generations who are called millennials according to the criteria specified in the instrument. Questionnaires distributed to 328 respondents, only 258 respondents returned and used in the final data set for analysis. Hence, the response rate of this study remains around $79 \%$. To reduce the problem, the writer first conducted a pretest of the instrument to be distributed. This is done to find out how far the respondents' understanding will be. After we have examined the Cronbach alpha and Pearson correlation, we understand that there was no more misunderstanding or ambiguity, then questionnaires were distributed. The data was checked carefully and thoroughly by the appointed team.

\section{Analysis and discussion}

This part will examine the results of the study. The analysis obtained descriptive statistics for this study. Descriptive statistical factor analysis was performed by looking into the pattern of correlation and covariance between the variables. The data obtained and evaluated using Statistical Package for Social Sciences Programmed (SPSS) version 26. The data already passed the reliable and validity test, and items of the indicators are obtaining valid, then all variables are reliable. This was pursued with relevant data analysis and assessment. The total number of respondents is 258 respondents. Majority of the respondents are millennial generations.

Table 1

The summary of regression analysis (Dependent variable: Financial technology)

\begin{tabular}{|c|c|c|c|c|c|c|c|c|c|c|}
\hline \multirow[b]{2}{*}{ Model } & \multirow[b]{2}{*}{$\mathrm{R}$} & \multirow[b]{2}{*}{ R Square } & \multirow[b]{2}{*}{$\begin{array}{c}\text { Adjusted R } \\
\text { Square }\end{array}$} & \multirow[b]{2}{*}{$\begin{array}{l}\text { Std. Error of } \\
\text { the Estimate }\end{array}$} & \multicolumn{5}{|c|}{ Change Statistics } & \multirow[b]{2}{*}{$\begin{array}{l}\text { Durbin- } \\
\text { Watson }\end{array}$} \\
\hline & & & & & $\begin{array}{l}\text { R Square } \\
\text { Change }\end{array}$ & F Change & $\mathrm{df1}$ & $\mathrm{df} 2$ & $\begin{array}{c}\text { Sig. F } \\
\text { Change }\end{array}$ & \\
\hline 1 & $.638^{\mathrm{a}}$ & .407 & .395 & 2.645 & .407 & 34.667 & 5 & 253 & .000 & 1.827 \\
\hline
\end{tabular}

a. Predictors: (Constant), B5, B1, B2, B4, B3

b. Dependent Variable: Total Fin

Table 2

The summary of the results of ANOVA test

\begin{tabular}{lllllll}
\hline \multicolumn{2}{l}{ Model } & Sum of Squares & df & Mean Square & F & Sig. \\
\hline \multirow{2}{1}{1} & Regression & 1480.473 & 5 & 296.095 & 49.856 & $.000^{\mathrm{b}}$ \\
& Residual & 1502.554 & 253 & 5.939 & & \\
\cline { 2 - 4 } & Total & 2983.027 & 258 & & & \\
\hline
\end{tabular}

a. Dependent Variable: Total Fin

b. Predictors: (Constant), Total EU, Total SE, Total Benefit, Total Security, Total Trust

Based on the result from ANOVA showed that significance level of sig is $0.000<0.005$ and $\mathrm{F}$ calculation $>\mathrm{F}$ table is 49.856 $>2.25$, so can be conclude that variable of benefit, trust, security, ease of use and self-efficacy have shown significance effect on financial technology of using GOPAY. Furthermore, it can be concluded that the regression model statistically significantly predicts the outcome variables. Fig. 2 presents the results of distribution of the dependent variable.

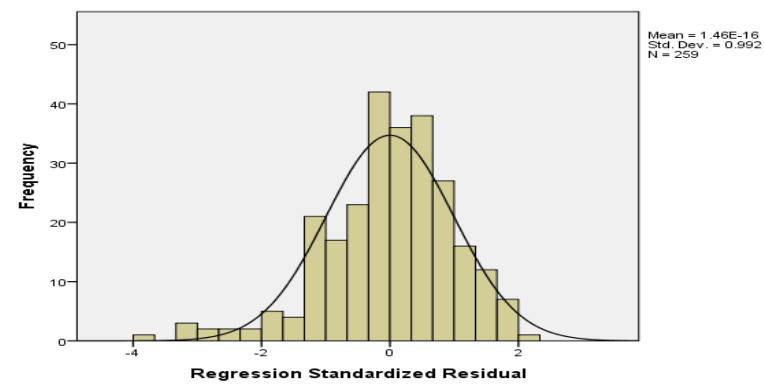

Fig. 2. Histogram - Dependent Variable: Financial Technology 
As we can observe from the figure, the distribution looks like a normal distribution. Table 3 presents the summary of the results of regression analysis.

Table 3

The summary of the regression analysis

\begin{tabular}{|c|c|c|c|c|c|c|c|c|c|}
\hline & & \multicolumn{2}{|c|}{ Unstandardized Coefficients } & \multicolumn{3}{|c|}{ Standardized Coefficients } & \multicolumn{3}{|c|}{ Correlations } \\
\hline \multicolumn{2}{|c|}{ Model } & $\mathrm{B}$ & Std. Error & Beta & $\mathrm{t}$ & Sig. & Zero-order & Partial & Part \\
\hline \multirow[t]{6}{*}{1} & (Constant) & .959 & 1.734 & & .553 & .581 & & & \\
\hline & Total Benefit & .474 & .108 & .290 & 4.399 & .000 & .606 & .267 & .196 \\
\hline & Total Trust & .059 & .091 & .046 & .650 & .516 & .513 & .041 & .029 \\
\hline & Total SE & -.046 & .083 & -.035 & -.554 & .580 & .397 & -.035 & -.025 \\
\hline & Total Security & .202 & .084 & .157 & 2.406 & .017 & .501 & .150 & .107 \\
\hline & Total EU & .445 & .089 & .357 & 5.024 & .000 & .651 & .301 & .224 \\
\hline
\end{tabular}

a. $\quad$ Dependent Variable: Total Fin

Significance level value from Trust is 0.516 , which is greater than 0.05 and $\mathrm{t}$ calculation value $0.650>\mathrm{t}$ table 2.015 can be explained variable of trust has significant effect towards financial or technology, therefore $\mathrm{H} 1$ is accepted. Significance level value from Self Efficacy is 0.580 , which is greater than 0.05 and $t$ calculation value $-0.554<\mathrm{t}$ table 2.015 can be explained as the variable of Self-Efficacy has negative effect towards financial of technology, therefore $\mathrm{H} 2$ is rejected. Based on the result above, Security significance level value is 0.017 , this is smaller than 0.05 and $t$ calculation value $2.406>t$ table 2.015 , therefore can be concluded there is significant effect of Security towards financial of technology, therefore $\mathrm{H} 3$ is accepted. Based on the table above, significance value level from Ease of use is 0.000 , which is smaller than 0.05 and t calculation value $5.024>\mathrm{t}$ table $2.015 \mathrm{can}$ be explained as the variable of ease of use has influence towards financial or technology, therefore $\mathrm{H} 4$ is accepted. Based on the table above, the significance of value level from Benefit is 0.000 , which is smaller than 0.05 and $\mathrm{t}$ calculation value $4.399>\mathrm{t}$ table 2.015 can be explained as the variable of benefit has greater significance effect towards financial or technology, therefore $\mathrm{H} 5$ is accepted.

Table 4

The result of KMO TEST

\begin{tabular}{|c|c|c|}
\hline Kaiser-Mey & & .563 \\
\hline Bartlett's Test of Sphericity & $\begin{array}{c}\text { Approx. Chi-Square } \\
\text { df } \\
\text { Sig. }\end{array}$ & $\begin{array}{c}54.857 \\
10 \\
.000\end{array}$ \\
\hline
\end{tabular}

a. Only cases for which Total Fin $=25$ are used in the analysis phase.

According to Kaiser (1974), the accepting value of KMO results is greater than 0.5 as acceptable values. These data the value is 0.563 , which about to show this factor analysis is appropriate for the model. Bartlett's Test Sphericity measures a null hypothesis that shows the original correlation matrix is an identity matrix. Furthermore, in this data, Bartlett's test of Sphericity is 54.857 with significance level of 0.000 , therefore factor analysis is appropriate.

Table 5

The result of Test of Eigenvalues

\begin{tabular}{|c|c|c|c|c|c|c|c|c|c|}
\hline \multirow[b]{2}{*}{ Component } & \multicolumn{3}{|c|}{ Initial Eigenvalues } & \multicolumn{3}{|c|}{ Extraction Sums of Squared Loadings } & \multicolumn{3}{|c|}{ Rotation Sums of Squared Loadings } \\
\hline & Total & $\%$ of Variance & Cumulative $\%$ & Total & $\%$ of Variance & Cumulative $\%$ & Total & $\%$ of Variance & Cumulative \% \\
\hline 1 & 2.650 & 53.002 & 53.002 & 2.650 & 53.002 & 53.002 & 2.125 & 42.503 & 42.503 \\
\hline 2 & 1.251 & 25.020 & 78.022 & 1.251 & 25.020 & 78.022 & 1.776 & 35.519 & 78.022 \\
\hline 3 & .638 & 12.754 & 90.776 & & & & & & \\
\hline 4 & .316 & 6.327 & 97.103 & & & & & & \\
\hline 5 & .145 & 2.897 & 100.000 & & & & & & \\
\hline
\end{tabular}

a. Only cases for which Total Fin $=25$ are used in the analysis phase.

This eigenvalue of variance explains 53.002 percent from total variance. Firstly, factors explained approximately huge numbers of variance whereas subsequent factors explain only little amounts of variance. Next extracts all factors with eigenvalues larger than 1, which leaves only two factors. Finally, extraction sums of squared loadings associated with the factors presented from the percentage of variance demonstrated, the values for the extraction table are the same value before the value extraction.

Table 6

The summary of the regression analysis

\begin{tabular}{|c|c|c|c|c|c|c|c|c|c|c|c|}
\hline \multirow[b]{2}{*}{ Model } & \multirow[b]{2}{*}{$\mathrm{R}$} & \multirow[b]{2}{*}{ R Square } & \multirow[b]{2}{*}{$\begin{array}{l}\text { Adjusted } \\
\text { Square }\end{array}$} & \multirow[b]{2}{*}{$\mathrm{R}$} & \multirow[b]{2}{*}{$\begin{array}{l}\text { Std. Error of } \\
\text { the Estimate }\end{array}$} & \multicolumn{5}{|c|}{ Change Statistics } & \multirow[b]{2}{*}{ Durbin-Watson } \\
\hline & & & & & & $\begin{array}{l}\mathrm{R} \text { Square } \\
\text { Change }\end{array}$ & F Change & df1 & $\mathrm{df} 2$ & $\begin{array}{l}\text { Sig. } \\
\text { Change } \\
\end{array}$ & \\
\hline 1 & $.758^{\mathrm{a}}$ & .574 & .566 & & 1.369 & .574 & 68.285 & 5 & 253 & .000 & 1.805 \\
\hline
\end{tabular}

a. Predictors: (Constant), Total Fin, Total SE, Total Trust, Total Security, Total EU

b. Dependent Variable: Total Benefit 
This table states the $\mathrm{R}$ and $\mathrm{R}^{2}$ values. The $\mathrm{R}$ value means the simple correlation and is 0.758 , which indicates a high degree of correlation. The $\mathrm{R}^{2}$ ( $\mathrm{R}$ Square) shows total variation in the dependent variable of benefit, which can be explained by the independent variables of financial technology, security, self-efficacy, trust, ease of use. In this case it is 57.4 percent, while the remaining 42.6 percent is explained by other variables which are not included in this research. Adjusted R-Square is 56.6 percent of the variance in the dependent variable is explained by the independent variables.

Table 7

The summary of the results of ANOVA test

\begin{tabular}{llccccc}
\hline Model & & Sum of Squares & df & Mean Square & F & \\
\hline 1 & Regression & 640.097 & 5 & 128.019 & 68.285 \\
& Residual & 474.320 & 253 & 1.875 & $.000^{\mathrm{b}}$ & \\
\cline { 2 - 6 } & Total & 1114.417 & 258 & & \\
\hline
\end{tabular}

a. Dependent Variable: Total Benefit

b. Predictors: (Constant), Total Fin, Total SE, Total Trust, Total Security, Total EU

Based on the result from ANOVA showed that significance level of sig is $0.000<0.005$ and $\mathrm{F}$ calculation $>\mathrm{F}$ table is 68.285 $>2.25$, so can be conclude that variable of financial technology, trust, security, ease of use and self-efficacy have shown significance effect on benefit of using GOPAY. Furthermore, it can be summarized that the regression model statistically significantly predicts the outcome variables.

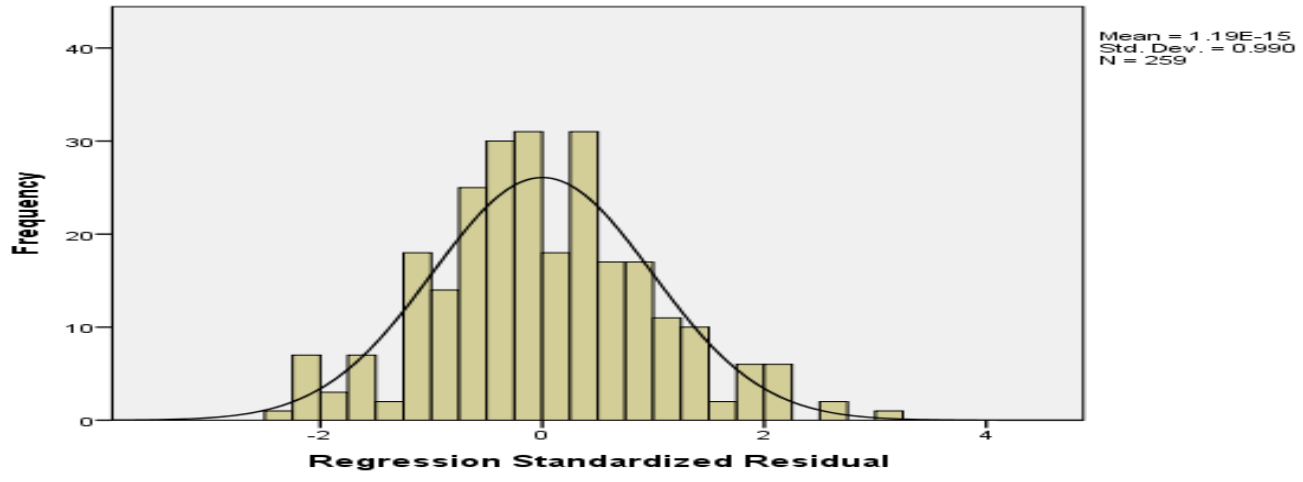

Fig. 3. Histogram - Dependent Variable Benefit

Table 8

The summary of regression analysis

\begin{tabular}{|c|c|c|c|c|c|c|c|c|c|c|}
\hline & & \multicolumn{2}{|c|}{$\begin{array}{c}\text { Unstandardized } \\
\text { Coefficients }\end{array}$} & \multirow{2}{*}{$\begin{array}{c}\text { Standardized } \\
\text { Coefficients } \\
\text { Beta } \\
\end{array}$} & \multirow[b]{2}{*}{$\mathrm{t}$} & \multirow[b]{2}{*}{ Sig. } & \multicolumn{2}{|c|}{$95.0 \%$ Confidence Interval for B } & \multicolumn{2}{|c|}{ Collinearity Statistics } \\
\hline \multicolumn{2}{|c|}{ Model } & $\mathrm{B}$ & Std. Error & & & & $\begin{array}{l}\text { Lower } \\
\text { Bound }\end{array}$ & Upper Bound & $\begin{array}{l}\text { Toler- } \\
\text { ance }\end{array}$ & VIF \\
\hline 1 & (Constant) & 8.168 & .829 & & 9.857 & .000 & 6.536 & 9.799 & & \\
\hline & Total Trust & .345 & .046 & .442 & 7.414 & .000 & .253 & .436 & .473 & 2.113 \\
\hline & Total SE & -.047 & .047 & -.059 & -1.007 & .315 & -.139 & .045 & .490 & 2.039 \\
\hline & Total Security & .071 & .048 & .090 & 1.490 & .138 & -.023 & .164 & .460 & 2.175 \\
\hline & Total EU & .131 & .052 & .172 & 2.548 & .011 & .030 & .233 & .368 & 2.715 \\
\hline & Total Fin & .150 & .034 & .245 & 4.399 & .000 & .083 & .217 & .542 & 1.844 \\
\hline
\end{tabular}

If sig value $<0.05$ and $\mathrm{T}$ calculation $>\mathrm{T}$ table, so that there is significant effect between independent variable and dependent variable. However, If sig value $>0.05$ and $\mathrm{T}$ calculation $<\mathrm{T}$ table, so that there is no significant effect between independent variable and dependent variable. Significance level value from Trust is 0.000 , which is smaller than 0.05 and $t$ calculation value $7.014>\mathrm{t}$ table 2.015 can be explaining variable of trust has significant effect towards benefit, therefore $\mathrm{H} 1$ is accepted.

Significance level value from Self Efficacy is 0.315 , which is greater than 0.05 and $\mathrm{t}$ calculation value $-1.007<\mathrm{t}$ table 2.015 can be explained as the variable of Self-Efficacy has negative effect towards benefit, therefore $\mathrm{H} 2$ is rejected.

Based on the result above, Security significance level value is 0.138 , this is greater than 0.05 and $t$ calculation value $1.490<$ $\mathrm{t}$ table 2.015, therefore can be concluded there is no significant effect of Security towards benefit, therefore H3 is rejected.

Based on the table above, significance value level from Ease of use is 0.030 , which is smaller than 0.05 and t calculation value $2.548>\mathrm{t}$ table 2.015 can be explained as the variable of ease of use has influence towards benefit, therefore H4 is accepted. 
Based on the table above, significance value level from Financial technology is 0.000 , which is smaller than 0.05 and t calculation value $4.399>\mathrm{t}$ table 2.015 can be explained as the variable of benefit has greater significance effect towards financial technology, therefore H5 is accepted.

Table 9

The summary of the KMO test

\begin{tabular}{lll}
\hline Kaiser-Meyer-Olkin Measure of Sampling Adequacy. & & .588 \\
Bartlett's Test of Sphericity & Approx. Chi-Square & 110.461 \\
& df & 10 \\
& Sig. & .000 \\
\hline
\end{tabular}

a. Only cases for which Total Benefit $=25$ are used in the analysis phase.

Kaiser (1974) recommends accepting the value of KMO results is greater than 0.5 as acceptable values. These data the value is 0.588 , which shows this factor analysis is appropriate for these data. Bartlett's Test Sphericity measures tests the null hypothesis that the original correlation matrix is an identity matrix. For these data, Bartlett's test of Sphericity is 110.461 with significance level of 0.000 , therefore factor analysis is appropriate.

Table 10

The result of Test of Eigenvalues

\begin{tabular}{|c|c|c|c|c|c|c|}
\hline \multirow[b]{2}{*}{ Component } & \multirow[b]{2}{*}{ Total } & \multicolumn{2}{|c|}{ Initial Eigenvalues } & \multicolumn{3}{|c|}{ Extraction Sums of Squared Loadings } \\
\hline & & $\%$ of Variance & Cumulative \% & Total & $\%$ of Variance & Cumulative $\%$ \\
\hline 1 & 2.704 & 54.082 & 54.082 & 2.704 & 54.082 & 54.082 \\
\hline 2 & .951 & 19.023 & 73.106 & & & \\
\hline 3 & .813 & 16.252 & 89.358 & & & \\
\hline 4 & .321 & 6.428 & 95.785 & & & \\
\hline 5 & .211 & 4.215 & 100.000 & & & \\
\hline
\end{tabular}

This eigenvalue of variance explains 54.082 percent of total variance. First factors explain relatively large amounts of variance whereas subsequent factors explain only small amounts of variance. Next extracts all factors with eigenvalues greater than 1 , which leaves only one factor. Extraction sums of squared loadings associated with the factors shown from the percentage of variance explained, the values in this extraction table are the same value before the value extraction.

\section{Conclusions}

In this study, the researchers wanted to prove how digital technology supports the community to survive during strict restrictions during the COVID-19 pandemic in the Jakarta area and its surroundings, in Indonesia. This study uses a model with a research framework as discussed in this study, and a literature review leads to the development of five hypotheses according to the framework image in fig. 1.

With the presence of digital application technology that is equipped with a financial technology payment platform as well as a food delivery feature to place the consumers. This technology becomes the revolution one to supply chain and others that applied to respective consumers with the interaction of digital technology. Such technology application is a new civilization that forced the people to use in the force majeure situation. This technology can be installed for both operations in IOS and android mobile devices that provide an online ordering that is safe, comfortable, useful and efficient as well as the delivery of goods and other services available in this application technology.

From the results of the discussion and the findings of this study, it shows that trust, self-efficiency, security and ease of use are felt, which significantly affect how useful technological applications are during the COVID19 pandemic. The benefit variable is also significant for influencing the intention to use digital technology, namely Finance Technology, the trust that is felt by the public, in this case the respondent in this study.

The presence of financial technology, especially during the Covid-19 pandemic, shows that it is very supportive for consumer resilience to survive. And the food industry and others that offer profitable business opportunities with national mutual cooperation in Indonesia. Thus, this becomes a new business and service model that gives birth to a digital payment service innovation strategy in the dynamics of maintaining the existing companies and open a lot of the startup business in this country.

\section{Acknowledgements}

The researchers would like to thank the Office of Research and Publication Faculty of Business and Economics, Universitas Pelita Harapan, Karawaci, Tangerang Indonesia for financial support for this exploration. 


\section{References}

Abbad, M. M. (2013). E-banking in Jordan. Behaviour and Information Technology, 32(7), 681-694.

Agag, G. M., \& El-Masry, A. A. (2017). Why Do Consumers Trust Online Travel Websites? Drivers and Outcomes of Consumer Trust toward Online Travel Websites. Journal of Travel Research, 56(3), 347-369.

Akintan, I., Dabiri, M., Jolaosho, S., \& Sanyaolu, W. (2019). An appraisal of sales promotion on consumer purchasing motives of MTN customer service centre, Abeokuta. International Journal of Information, Business and Management, 11(3), 1633.

Alt, R., Beck, R., \& Smits, M. T. (2018). FinTech and the transformation of the financial industry. Electronic Markets, 28(3), 235-243.

Amajida, F. D. (2016). Kreativitas Digital Dalam Masyarakat Risiko Perkotaan: Studi Tentang Ojek Online “Go-Jek” Di Jakarta. Informasi, 46(1), 115.

Bandura, A. (1982). Self-efficacy mechanism in human agency. American Psychologist, 37(2), 122-147.

Bandura, A. (1999). Social cognitive theory: An agentic Albert Bandura. Asian Journal of Social Psychology, 21-41.

Ben Sedrine, S., Bouderbala, A., \& Nasraoui, H. (2020). Leadership style effect on virtual team efficiency: trust, operational cohesion and media richness roles. Journal of Management Development.

Cassar, G., \& Friedman, H. L. (2011). Does Self-Efficacy Affect Entrepreneurial Investment? SSRN Electronic Journal, 3, 241-260.

Chandra, S., Srivastava, S. C., \& Theng, Y.-L. (2010). Evaluating the Role of Trust in Consumer Adoption of Mobile Payment Systems: An Empirical Analysis. Communications of the Association for Information Systems, 27.

Choi, S. (2018). What promotes smartphone-based mobile commerce? Mobile-specific and self-service characteristics. Internet Research, 28(1), 105-122.

Damaini, A. A., Nugroho, G. S., \& Suyoto. (2018). Fraud crime mitigation of mobile application users for online transportation. International Journal of Interactive Mobile Technologies, 12(3), 153-167.

Davis, F. D. (1989). Perceived usefulness, perceived ease of use, and user acceptance of information technology. MIS Quarterly: Management Information Systems, 13(3), 319-339. https://doi.org/10.2307/249008

Dorfleitner, G., Hornuf, L., Schmitt, M., \& Weber, M. (2017). FinTech in Germany. In FinTech in Germany. https://doi.org/10.1007/978-3-319-54666-7

Dranev, Y., Frolova, K., \& Ochirova, E. (2019). The impact of fintech M\&A on stock returns. Research in International Business and Finance, 48, 353-364. https://doi.org/10.1016/j.ribaf.2019.01.012

Fang, Y., Qureshi, I., Sun, H., McCole, P., Ramsey, E., \& Lim, K. H. (2014). Trust, satisfaction, and online repurchase intention: The moderating role of perceived effectiveness of e-commerce institutional mechanisms. MIS Quarterly: Management Information Systems, 38(2), 407-427. https://doi.org/10.25300/MISQ/2014/38.2.04

Financial Stability Board. (20209). The Use of Supervisory and Regulatory Technology by Authorities and Regulated Institutions: Market developments and financial stability implications. October, 76.

Fryer, L. K., Thompson, A., Nakao, K., Howarth, M., \& Gallacher, A. (2020). Supporting self-efficacy beliefs and interest as educational inputs and outcomes: Framing AI and Human partnered task experiences. Learning and Individual Differences, 80(February), 101850. https://doi.org/10.1016/j.lindif.2020.101850

Ghozali, I. (2014). Structural Equation Modeling: Teori, Konsep Dan Aplikasi Dengan Program Lisrel 9.10. Konsorsium Hukum Progresif Universitas Diponegoro.

Giudici, P. (2018). Financial data science. Statistics and Probability Letters, 136(40), 160-164.

Gomber, P., Koch, J. A., \& Siering, M. (2017). Digital Finance and FinTech: current research and future research directions. Journal of Business Economics, 87(5), 537-580. https://doi.org/10.1007/s11573-017-0852-x

Guo, Y., \& Liang, C. (2016). Blockchain application and outlook in the banking industry. Financial Innovation, 2(1).

Hu, Z., Ding, S., Li, S., Chen, L., \& Yang, S. (2019). Adoption intention of fintech services for bank users: An empirical examination with an extended technology acceptance model. Symmetry, 11(3). https://doi.org/10.3390/sym11030340

Iman, N. (2020). The rise and rise of financial technology: The good, the bad, and the verdict. Cogent Business and Management, 7(1).

International, K. (2019). Securing the future of financial services. 1-10.

Ji-Eun, L., \& Minsoo, S. (2011). Factors for the Adoption of Smartphone-based Mobile Banking: On User's Technology Readiness and Expertise. The Korean Journal of Electronic Commerce, 16(4), 155-172.

Junjie, Z. (2017). Exploring the factors affecting learners' continuance intention of moocs for online collaborative learning: An extended ecm perspective. Australasian Journal of Educational Technology, 33(5), 123-135.

Kaiser, H. F. (1974). An Index of Factorial Simplicity. Psychometrika, 39, 31-36.

Kang, J. (2018). Mobile payment in Fintech environment: trends, security challenges, and services. Human-Centric Computing and Information Sciences, 8(1). https://doi.org/10.1186/s13673-018-0155-4

Kesharwani, A., \& Bisht, S. S. (2012). The impact of trust and perceived risk on internet banking adoption in India: An extension of technology acceptance model. International Journal of Bank Marketing, 30(4), 303-322.

Kim, C., Tao, W., Shin, N., \& Kim, K. S. (2010). An empirical study of customers' perceptions of security and trust in epayment systems. Electronic Commerce Research and Applications, 9(1), 84-95.

Kim, D. J., Ferrin, D. L., \& Rao, H. R. (2008). A trust-based consumer decision-making model in electronic commerce: The role of trust, perceived risk, and their antecedents. Decision Support Systems, 44(2), 544-564. 
Kim, K. (2000). Initial Trust, Perceived Risk, and. 537-543.

Kim, Y., Choi, J., Park, Y., \& Yeon, J. (2016). The Adoption of Mobile Payment Services for “Fintech.” International Journal of Applied Engineering Research. https:/www.semanticscholar.org/paper/The-Adoption-of-Mobile-Payment-Servicesfor-Kim-Choi/2c968789b918883f6f189943f325b44aa69c9b9c

Kim, Y. J., Park, Y.-J., Choi, J., \& Yeon, J. (2015). An Empirical Study on the Adoption of “Fintech" Service: Focused on Mobile Payment Services. April, 136-140. https://doi.org/10.14257/astl.2015.114.26

Koksal, M. H. (2016). The intentions of Lebanese consumers to adopt mobile banking. International Journal of Bank Marketing, 34(3), 327-346. https://doi.org/10.1108/IJBM-03-2015-0025

Lee, D. K. C., \& Teo, E. G. S. (2015). Emergence of Fintech and the Lasic Principles. SSRN Electronic Journal, January 2015. https://doi.org/10.2139/ssrn.2668049

Lee, I., \& Shin, Y. J. (2018). Fintech: Ecosystem, business models, investment decisions, and challenges. Business Horizons, 61(1), 35-46. https://doi.org/10.1016/j.bushor.2017.09.003

Lee, M. C. (2009). Factors influencing the adoption of internet banking: An integration of TAM and TPB with perceived risk and perceived benefit. Electronic Commerce Research and Applications, 8(3), 130-141.

Leong, C., Tan, B., Xiao, X., Tan, F. T. C., \& Sun, Y. (2017). Nurturing a FinTech ecosystem: The case of a youth microloan startup in China. International Journal of Information Management, 37(2), 92-97.

Leong, K. (2018). FinTech (Financial Technology): What is It and How to Use Technologies to Create Business Value in Fintech Way? International Journal of Innovation, Management and Technology, 9(2), 74-78.

Li, M., Dong, Z. Y., \& Chen, X. (2012). Factors influencing consumption experience of mobile commerce: A study from experiential view. Internet Research, 22(2), 120-141. https://doi.org/10.1108/10662241211214539

Lu, Y., Yang, S., Chau, P. Y. K., \& Cao, Y. (2011). Dynamics between the trust transfer process and intention to use mobile payment services: A cross-environment perspective. Information and Management, 48(8), 393-403.

Malaquias, R. F., \& Hwang, Y. (2016). An empirical study on trust in mobile banking: A developing country perspective. Computers in Human Behavior, 54, 453-461.

Mcknight, D. H., Carter, M., Thatcher, J. B., \& Clay, P. F. (2011). Trust in a specific technology: An investigation of its components and measures. ACM Transactions on Management Information Systems, 2(2).

Mcknight, D. H., Choudhury, V., \& Kacmar, C. (2002). Developing and Validating Trust Measures for e-Commerce: An Integrative Typology. Information Systems Research, 13(3), 334-359. https://doi.org/10.7507/1672-2531.201806071

Murthy, G., Fernandez-Vidal, M., Faz, X., \& Barreto, R. (2019). FINTECHS AND FINANCIAL INCLUSION Looking past the hype and exploring their potential. Cgap, May. www.cgap.org

Narwal, P., \& Nayak, J. K. (2019). Towards a new price discrimination strategy: Exploring Pay-What-You-Want pricing in multi-channel retailing. Asia Pacific Journal of Marketing and Logistics, 32(4), 975-998.

Ozili, P. K. (2018). Impact of digital finance on financial inclusion and stability. Borsa Istanbul Review, 18(4), 329-340.

Pavlou, P. A., \& Fygenson, M. (2006). Understanding and predicting electronic commerce adoption: An extension of the theory of planned behavior. MIS Quarterly: Management Information Systems, 30(1), 115-143.

Pedler, M. (2020). On social action*. Action Learning: Research and Practice, 17(1), 1-9.

Rifusua, A. I. (2010). Analisis Faktor-Faktor yang Mempengaruhi Permintaan Busway Di DKI Jakarta Tahun 2004 - 2008. Perencanaan Dan Kebijakan Publik Universitas Indonesia, 1996, 10-38.

Riquelme, H. E., \& Rios, R. E. (2010). The moderating effect of gender in the adoption of mobile banking. International Journal of Bank Marketing, 28(5), 328-341. https://doi.org/10.1108/02652321011064872

Ryu, H.-S. (2018). Understanding Benefit and Risk Framework of Fintech Adoption: Comparison of Early Adopters and Late Adopters. Proceedings of the 51st Hawaii International Conference on System Sciences, 3864-3873.

San-Martín, S., Jimenez, N., Camarero, C., \& San-José, R. (2020). The path between personality, self-efficacy, and shopping regarding games apps. Journal of Theoretical and Applied Electronic Commerce Research, 15(2), 59-75.

Schueffel, P. (2017). Taming the Beast: A Scientific Definition of Fintech. Journal of Innovation Management, 4(4), $32-54$.

Shea, P., \& Bidjerano, T. (2010). Learning presence: Towards a theory of self-efficacy, self-regulation, and the development of a communities of inquiry in online and blended learning environments. Computers and Education, 55(4), $1721-1731$.

Shiau, W. L., Yuan, Y., Pu, X., Ray, S., \& Chen, C. C. (2020). Understanding fintech continuance: perspectives from selfefficacy and ECT-IS theories. Industrial Management and Data Systems, 120(9), 1659-1689.

Slade, E. L., Dwivedi, Y. K., Piercy, N. C., \& Williams, M. . (2015). Cronfa - Swansea University Open Access Repository Modeling consumers' adoption intentions of remote mobile payments in the UK: Extending UTAUT with innovativeness, risk and trust Emma L Slade* School of Management, Swansea University, Swansea, UK. Psychology \& Marketing, 32, 860-873., 32(8), 860-873. https://www.semanticscholar.org/paper/Modeling-Consumers'-AdoptionIntentions-of-Remote-Slade-Dwivedi/43a002fa82d1 eea5d2bb46d22c1 efdaf4e6c4ac0

Strzelecki, A., \& Rizun, M. (2020). Consumers' security and trust for online shopping after GDPR: examples from Poland and Ukraine. Digital Policy, Regulation and Governance , 22(4), 289-305. https://doi.org/10.1108/DPRG-06-2019-0044

Sugiyono. (2018). Metode Penelitian Kuantitatif, Kualitatif, dan R\&D. Alfabeta.

Sun, B., \& Saenko, K. (2016). Return of frustratingly easy domain adaptation |. Aaai, 1, $2058-2065$. https://dl.acm.org/doi/10.5555/3016100.3016186

Teoh, W. M. Y., Chong, S. C., Lin, B., \& Chua, J. W. (2013). Factors affecting consumers' perception of electronic payment: An empirical analysis. Internet Research, 23(4), 465-485. https://doi.org/10.1108/IntR-09-2012-0199

Thompson, B. S. (2017). Can Financial Technology Innovate Benefit Distribution in Payments for Ecosystem Services and 
REDD+? Ecological Economics, 139, 150-157. https://doi.org/10.1016/j.ecolecon.2017.04.008

Tsiakis, T. (2012). Consumers' Issues and Concerns of Perceived Risk of Information Security in Online Framework. The Marketing Strategies. Procedia - Social and Behavioral Sciences, 62, 1265-1270.

Venkatesh, V., Davis, F. D., \& College, S. M. W. (2000). Theoretical Acceptance Extension Model:Four Longitudinal Field Studies. Management Science, 46(2), 186-204.

Waheed, M., Khan, Q., \& Noor-Ul-Ain. (2013). Role of Satisfaction, Security and Risk Towards Customer's Turnover Intention from Traditional to Internet Banking. International Arab Journal of E-Technology, 3(May), 83-89.

Wonglimpiyarat, J. (2017). FinTech banking industry: a systemic approach. Foresight, 19(6), $590-603$. https://doi.org/10.1108/FS-07-2017-0026

Wonglimpiyarat, J. (2018). Challenges and dynamics of FinTech crowd funding: An innovation system approach. Journal of High Technology Management Research, 29(1), 98-108. https://doi.org/10.1016/j.hitech.2018.04.009

Wu, J., Liu, L., \& Huang, L. (2016). Exploring user acceptance of an innovative mobile payment service in an emerging market: The moderating effect of the diffusion stages of WeChat payments in China. Pacific Asia Conference on Information Systems, PACIS 2016 - Proceedings, June.

Xin, H., Techatassanasoontorn, A. A., \& Tan, F. B. (2015). Antecedents of consumer trust in mobile payment adoption. Journal of Computer Information Systems, 55(4), 1-10. https://doi.org/10.1080/08874417.2015.11645781

Xue, W., Sun, Y., Bandyopadhyay, S., \& Cheng, D. (2021). Measuring customer equity in noncontractual settings using a diffusion model: An empirical study of mobile payments aggregator. Journal of Theoretical and Applied Electronic Commerce Research, 16(3), 409-431. https://doi.org/10.3390/jtaer16030026

Yokoyama, S. (2019). Academic self-efficacy and academic performance in Online Learning: A mini review. Frontiers in Psychology, 9(JAN), 1-4. https://doi.org/10.3389/fpsyg.2018.02794

Zheng, T., Chen, G., Wang, X., Chen, C., Wang, X., \& Luo, S. (2019). Real-time intelligent big data processing: technology, platform, and applications. Science China Information Sciences, 62(8), 1-12. https://doi.org/10.1007/s11432-018-9834-8

Zhou, T. (2013). An empirical examination of continuance intention of mobile payment services. Decision Support Systems, 54(2), 1085-1091. https://doi.org/10.1016/j.dss.2012.10.034

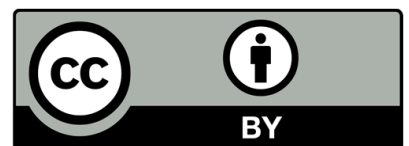

(C) 2021 by the authors; licensee Growing Science, Canada. This is an open access article distributed under the terms and conditions of the Creative Commons Attribution (CC-BY) license (http://creativecommons.org/licenses/by/4.0/). 